\title{
PERAN APELIN PADA PENYAKIT GINJAL KRONIK
}

\author{
Gina Ariani ${ }^{1)}$, Harnavi Harun ${ }^{2)}$ \\ ${ }^{1}$ PPDS Ilmu Penyakit Dalam Fakultas Kedokteran Universitas Andalas/RSUP M. Djamil Padang \\ email: gina.hagia@gmail.com \\ ${ }^{2}$ Subbagian Ginjal Hipertensi Ilmu Penyakit Dalam Fakultas Kedokteran Universitas Andalas/RSUP M. Djamil \\ Padang
}

Submitted : 29-05-2020, Reviewer: 30-05-2020, Accepted: 31-05-2020

\begin{abstract}
Abstrak
Penyakit ginjal kronik (PGK) merupakan kelainan struktur atau fungsi ginjal yang berlangsung dalam waktu $\geq 3$ bulan. Kelainan struktur atau fungsi ginjal ini ditandai dengan salah satu atau lebih kriteria yaitu terdeteksinya albuminuria $>30 \mathrm{mg} / 24 \mathrm{jam}$, kelainan sedimen urin, kelainan yang ditemukan dari pemeriksaan histologi, kelainan struktural yang terdeteksi melalui imaging, riwayat transplantasi ginjal dan penurunan laju filtrasi glomerulus (LFG) $<60 \mathrm{ml} / \mathrm{menit} / 1,73 \mathrm{~m}$. Komplikasi utama dari penyakit ini tidak hanya mencakup perkembangan ke penyakit ginjal stadium akhir, tetapi juga peningkatan risiko komplikasi seperti penyakit kardiovaskular dan stroke yang merupakan penyebab utama morbiditas dan mortalitas pasien dengan PGK pada semua stadium. Sehingga dianjurkan untuk dilakukan deteksi dini dan terapi untuk mencegah prognosis yang buruk. Apelin merupakan peptida vasoaktif yang berperan sebagai ligan reseptor selektif, APJ, yang secara genetis diidentifikasi memiliki identitas terdekat dengan reseptor angiotensin II tipe 1 (AT-1). Terdapat berbagai peran sistem apelin-APJ dalam fisiologi manusia termasuk regulasi fungsi kardiovaskular dan homeostasis cairan. Terlepas dari homologi yang tinggi antara reseptor APJ dan reseptor AT-1, sistem apelin-APJ telah diketahui memiliki kerja yang berlawanan terhadap angiotensin II tipe 1. Peran apelin-APJ dalam fisiologi ginjal, termasuk dalam homeostasis cairan di ginjal. Selain itu, efek renoprotektif dari sistem apelin-APJ pada penyakit ginjal telah dilaporkan dalam kejadian fibrosis ginjal, cedera ginjal iskemik / reperfusi (I / R) dan nefropati diabetes, yang menunjukkan bahwa sistem apelin-APJ dapat menjadi target terapeutik yang baru untuk penyakit ginjal kronik.
\end{abstract}

Kata Kunci: Penyakit Ginjal Kronik, Apelin,

\begin{abstract}
Chronic kidney disease (CKD) is a structural or functional abnormality of the kidneys that lasts for $\geq 3$

months. This structural or functional abnormality of the kidney is characterized by one or more criteria: detection of albuminuria $>30 \mathrm{mg} / 24$ hours, urinary sediment abnormalities, abnormalities that found from histological examination, structural abnormalities detected through imaging, history of kidney transplantation and decreased glomerular filtration rate ( LFG) $<60 \mathrm{ml} / \mathrm{minute} / 1.73 \mathrm{~m}$. The main complications of this disease include not only progression to end-stage renal disease, but also an increased risk of complications such as cardiovascular disease and stroke which are the main causes of morbidity and mortality in patients with CKD at all stages. So it is recommended to do early detection and therapy to prevent a poor prognosis. Apelin is a vasoactive peptide that acts as a selective receptor ligand, APJ, which is genetically identified as having the closest identity to angiotensin II type 1 (AT-1) receptors. There are various roles of the apelin-APJ system in human physiology including regulation of cardiovascular function and fluid homeostasis. Apart from the high homology between the APJ receptor and the AT-1 receptor, the apelin-APJ system has been known to have the opposite action against angiotensin II type 1. The role of apelin-APJ in renal physiology, including fluid homeostasis in the
\end{abstract}


kidney. In addition, the renoprotective effect of the apelin-APJ system on kidney disease has been reported in the incidence of renal fibrosis, ischemic / reperfusion (I / R) kidney injury and diabetes nephropathy, which shows that the apelin-APJ system can be a new therapeutic target for kidney disease chronic.

Keywords: Chronic kidney disease, Apelin

\section{PENDAHULUAN}

Penyakit ginjal kronik merupakan masalah kesehatan yang sangat serius dimana prevalensi PGK telah meningkat dalam beberapa tahun terakhir, baik di negara maju maupun negara berkembang. Perkembangan PGK dikaitkan dengan morbiditas dan mortalitas yang tinggi. Perkembangan PGK menjadi penyakit ginjal stadium akhir tetap menjadi masalah kesehatan utama di dunia. Hal tersebut mengisyaratkan untuk melakukan upaya pencegahan terjadinya PGK serta upaya untuk menghambat progresifitas penyakit tersebut.

Penyakit ginjal kronik mempengaruhi lebih dari $10 \%$ populasi di hampir seluruh negara di dunia. Pada tahun 2010, di seluruh dunia diperkirakan 284 individu per juta populasi yang harus dijalani hemodialisis. ${ }^{1}$ Di Amerika Serikat terdapat $15 \%$ orang dewasa atau sekitar 37 juta orang diperkirakan menderita PGK. PGK merupakan penyakit dengan beban biaya kesehatan masyarakat yang tinggi. Pada pasien PGK yang tidak dilakukan hemodialisis menghabiskan 18,2\% dari total pengeluaran kesehatan yaitu sekitar \$ 45,5 juta. $^{2}$

Data di beberapa bagian nefrologi di Indonesia, diperkirakan insiden PGK berkisar 100-150 kasus per 1 juta penduduk dan prevalensi mencapai 400 kasus per 1 juta penduduk. Data dari Perhimpunan Nefrologi Indonesia (PERNEFRI) dalam Program Indonesian Renal Registry (IRR) melaporkan jumlah pasien PGK tahun 2017 tercatat 30.831 pasien baru PGK yang menjalani hemodialisis. Dari data yang dikumpulkan oleh Indonesian Renal Registry (IRR) tahun 2017 ini, etiologi atau penyakit dasar dari pasien PGK yaitu hipertensi menempati urutan pertama yaitu $36 \%$, diabetes mellitus sebagai etiologi kedua yaitu $29 \%$, diikuti penyebab lain yaitu glomerulopati primer $12 \%$, pielonefritis $7 \%$, dan nefropati obstruksi 4\%. Penyebab mortalitas terbanyak pada pasien PGK hemodialisis adalah akibat komplikasi kardiovaskuler sebanyak $41 \% .^{3}$

Penyakit ginjal kronik ditandai oleh perkembangan glomerulosklerosis progresif, fibrosis interstitial dan atrofi tubular yang terjadi bersamaan dengan penurunan Glomerular Filtration Rate (GFR). Beberapa faktor terkait dengan proses perkembangan PGK seperti obesitas, hipertensi dan diabetes mellitus. Di luar faktor-faktor tersebut, terdapat peran inflamasi pada PGK. Beberapa sitokin dan kemokin memiliki peran penting pada tahap awal PGK, yang juga berkaitan dengan komplikasi dari PGK. Inflamasi meningkatkan risiko kardiovaskular yang akan meningkatkan angka mortalitas pasien PGK. Inflamasi terkait dengan peningkatan efek stress oksidatif, resistensi insulin dan disfungsi endotel yang dianggap sebagai faktor risiko kardiovaskuler pada PGK. ${ }^{4}$

Apelin adalah adipositokin yang baru ditemukan dan diproduksi dari jaringan adiposa putih. Apelin merupakan ligan endogen untuk reseptor APJ Gprotein-coupled yang diekspresikan pada permukaan beberapa jenis sel. Apelin banyak terdapat pada berbagai organ seperti jantung, paru-paru, ginjal, hati, jaringan adiposa, otak, kelenjar adrenal, endotelium, dan plasma manusia. ${ }^{5}$ Sistem apelin-APJ 
memiliki peran dalam regulasi fungsi kardiovaskular. Apelin yang diekspresikan oleh rektus arteriolar glomerular dan sel kapiler glomerulus memiliki peran dalam fisiologi ginjal termasuk keseimbangan homeostasis di ginjal. Selain itu, efek renoprotektif dari sistem apelin-APJ pada penyakit ginjal telah diketahui dalam kondisi fibrosis ginjal, cedera ginjal iskemik / reperfusi (I / R) dan nefropati diabetes. Sistem apelin-APJ memiliki peran dalam fisiologi ginjal dan hal tersebut mungkin menjadi target terapeutik baru untuk penyakit ginjal kronik.

\section{SEJARAH APELIN}

Pada tahun 1993, O'Dowd mengidentifikasi gen yang mengkode reseptor G-protein-coupled dengan 380 asam amino. Reseptor ini yang diberi nama APJ, memiliki homologi yang tinggi dengan reseptor angiotensin II tipe 1 (AT-1) pada manusia. ${ }^{5}$

Apelin pertama kali ditemukan pada tahun 1993, saat protein reseptor yang berkaitan dengan reseptor angiotensin yang dikloning selama pencarian protein baru yang digabungkan dengan reseptor yang memiliki 7-transmembran domain. Protein ini merupakan protein seperti reseptor angiotensin (AGTRL1) yang dikenal dengan APJ dan banyak terdapat di otak. Serta organ lain Gen APJ secara lebih lanjut dipetakan ke kromosom 11 dan kemudian sublokalisasi ke lokus 11q12. Salah satu karakteristik utamanya adalah APJ tidak dapat berinteraksi dengan angiotensin II. ${ }^{5}$

\section{DEFINISI APELIN}

Apelin adalah adipositokin yang baru ditemukan dan diproduksi dari jaringan adiposa putih. Terdapat beberapa bentuk molekul apelin yaitu apelin-13, apelin-17, dan apelin-36. Bentuk apelin tersebut didapatkan dari 77-prekursor preproapelin asam amino. Efeknya adalah melalui sel yang disebut reseptor protein-coupled APJ, yang memiliki kesamaan struktural dengan reseptor angiotensin. ${ }^{6}$

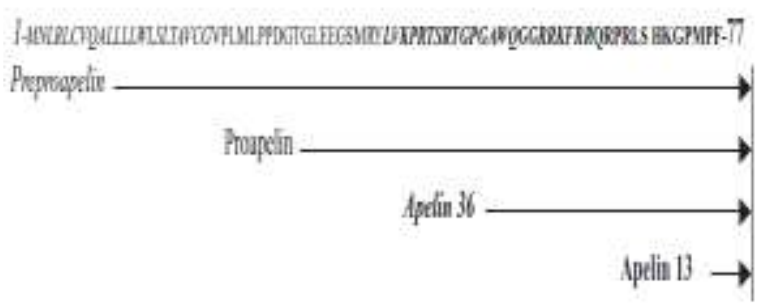

Gambar 1.Urutan Peptida dari preproapelin ${ }^{6}$

Reseptor APJ melalui pemeriksaan polymerase chain reaction (PCR) terdapat di nefron. Ekspresi mRNA reseptor APJ paling tinggi pada medulla ginjal dan paling rendah pada korteks ginjal. Di sepanjang nefron, ekspresi mRNA reseptor APJ sangat tinggi pada glomerulus dan berjumlah sedang pada segmen nefron lain dari tubulus proksimal. ${ }^{7}$

\section{PERAN APELIN PADA PENYAKIT GINJAL KRONIKS}

Keterlibatan sistem apelin-APJ dalam perkembangan fibrosis jaringan telah diperlihatkan pada fibrosis ginjal. Efek antifibrotik dari apelin yang melawan Ang II telah dilaporkan pada kondisi fibrosis jantung dan fibrosis ginjal. Pada tikus dengan fibrosis ginjal, sistem apelin-APJ terbukti berperan pada efek pengurangan ARB pada fibrosis ginjal. Salah satu mekanisme utama apelin melalui reseptor APJ adalah produksi nitrit oxide di endothelium melalui jalur Akt / endothelial nitric oxide synthase (eNOS), yang menyebabkan vasodilatasi. ${ }^{8}$

Apelin menghambat aktivasi fibroblas jantung melalui TGF- $\beta$ dengan pengurangan aktivitas sphingosine kinase 1 (SphK1). Hasil ini meningkatkan kemungkinan 
pilihan terapeutik yang menargetkan apelin / APJ pada pengobatan fibrosis ginjal. ${ }^{9}$

Apelin memiliki efek renoprotektif terhadap cedera iskemia / reperfusi ginjal (I / R). Dalam model tikus percobaan dengan cedera I/R, pemberian apelin-13 intraperitoneal selama tiga hari berturutturut sebelum prosedur pembedahan mengakibatkan penurunan kadar ureum dan kreatinin dalam darah dan terdapat peningkatan laju filtrasi glomerulus serta terdapat perbaikan terhadap kerusakan histologis ginjal. TGF- $\beta 1$ berkaitan erat dengan fibrosis ginjal dan inflamasi. ${ }^{10}$

Efek perlindungan dari apelin-13 pada cedera I / R ginjal diketahui dari penelitian Bircan et al. Hasil menunjukkan bahwa pemberian apelin-13 dapat meningkat kan kadar urea nitrogen darah serum (BUN), kreatinin, dan tumor necrosis factor alpha (TNF- $\alpha$ ). Karena itu, penghambatan TGF- $\beta 1$ mungkin terkait dengan efek protektif dari apelin-13 pada cedera ginjal. Selain itu, apelin-13 meningkat aktivitas enzim antioksidan, mencegah oksidasi lipid dan meningkatkan fungsi ginjal pada I / R ginjal. $^{11}$

Nefropati diabetik merupakan salah satu komplikasi utama pada diabetes, dan juga yang etiologi paling banyak pada penyakit ginjal tahap akhir ${ }^{12}$. Manifestasi klinis awal nefropati diabetik termasuk hipertrofi glomerulus dan penebalan membran dasar glomerulus. Dengan adanya perkembangan penyakit, filtrasi glomerulus yang tinggi dapat menyebabkan proteinuria, yang akhirnya berkembang penyakit ginjal stadium akhir. Studi menunjukkan bahwa sistem apelin-APJ memainkan peran penting dalam nefropati diabetik. Dibandingkan dengan pasien sehat, pasien dengan diabetes tipe 2 tampaknya memiliki kadar serum apelin lebih tinggi. Kadar albumin urin dan apelin serum memiliki korelasi positif. ${ }^{13}$
Selain itu, apelin meningkatkan kadar protein urin dan rasio kreatinin pada tikus. Apelin meningkatkan migrasi dan proliferasi sel endotel glomerulus. Peningkatan apelin meningkatkan permeabilitas sel endotel glomerulus, dan meningkatkan faktor pertumbuhan endotel pembuluh darah dan ekspresi adenosin difosfat. ${ }^{13}$

Beberapa penelitian juga menunjukkan bahwa sistem apelin-APJ dapat menginduksi produksi sel endotel secara autokrin atau parakrin. Oleh karena itu, apelin dapat meningkatkan angiogenesis glomerulus, memperbaiki pembuluh darah yang rusak melalui growth factor pada endotel pembuluh darah pada diabetes mellitus tipe 2. ${ }^{14}$

Apelin dapat memperlambat perkembangan nefropati diabetik. Day et al (2013) mempelajari tikus dengan diabetes tipe 1 menerima suntikan apelin subkutan setiap hari selama 2 atau 14 minggu. Pada penelitian ini diketahui bahwa apelin tidak mempengaruhi glukosa darah, berat badan dan tekanan darah, tetapi menghambat terjadinya hipertrofi ginjal dan glomerulus, serta inflamasi ginjal. Serta apelin dapat mengurangi ekspresi monocyte chemoattractant-1 (MCP-1) dan vascular cell adhesion molecule 1 (VCAM1), aktivasi $\mathrm{NF}-\kappa \mathrm{B}$ dan infiltrasi monosit. Sehingga memungkinkan apelin dapat digunakan sebagai terapi baru untuk pengobatan nefropati diabetik. ${ }^{15}$

Namun, beberapa penelitian meyakini bahwa apelin juga dapat meningkatkan progresifitas terjadinya nefropati diabetik. Kerusakan podosit berkaitan erat dengan perkembangan nefropati diabetik. Apelin dapat menginduksi gangguan fungsi podosit melalui penghambatan aktivitas proteasome yang meningkatkan perkembangan menuju nefropati. ${ }^{16}$ 
Apelin dapat meningkatkan proteinuria pada tikus percobaan dan mengurangi ekspresi protein pada podosit. Hal ini konsisten dengan peningkatan kadar apelin di glomerulus pada pasien dengan nefropati diabetik. Meningkatnya ekspresi apelin pada kadar glukosa tinggi mempengaruhi podosit dan injeksi apelin-13 pada tikus percobaan menyebabkan terjadi proteinuria dan peningkatan permeabilitas. ${ }^{16}$

Nefropati diabetik merupakan proses yang kompleks. Peran apelin terkait dengan banyak faktor terjadinya dan perkembangan nefropati itu sendiri, seperti resistensi insulin, obesitas dan gangguan metabolisme glikolipid. Karena itu, peran sistem apelinAPJ dalam perkembangan nefropati diabetik masih kontroversial, yang masih membutuhkan penelitian lebih lanjut. ${ }^{16}$

Kalsifikasi pembuluh darah dikaitkan dengan peningkatan risiko kejadian kardiovaskular, yang merupakan penyebab mortalitas paling umum pada pasien dengan PGK. ${ }^{17}$ Apelin secara efektif dapat menahan diferensiasi osteoblas dalam kalsifikasi sel otot polos pembuluh darah. ${ }^{18}$ Han et al (2016) dalam penelitiannya menunjukkan bahwa apelin menghambat kalsifikasi pembuuh darah pada penyakit ginjal kronik. $^{19}$

\section{SIMPULAN}

Apelin merupakan ligan endogen untuk reseptor APJ G-protein -coupled yang diekspresikan pada permukaan beberapa jenis sel. Apelin banyak didapatkan di berbagai organ seperti jantung, paru-paru, ginjal, hati, jaringan adiposa.

Sistem apelin-APJ memainkan berbagai fungsi biologis pada penyakit ginjal. Pemberian apelin-13 menyebabkan penurunan kadar urea dan kreatinin dalam darah dan peningkatan laju filtrasi glomerulus serta penurunan kerusakan histologis ginjal.
Namun, sistem apelin-APJ memainkan peran ganda dalam beberapa penyakit ginjal kronik misalnya pada yang disebabkan oleh nefropati diabetik. Sistem apelin-APJ memiliki efek vasodilatasi, menurunkan tekanan darah, meningkatkan kekuatan kontraksi miokard. Namun, sistem apelinAPJ dapat juga meningkatkan terjadinya nefropati diabetik. Diperlukan lebih banyak penelitian lebih lanjut untuk memahami mekanisme dan peran baru sistem apelinAPJ pada penyakit ginjal kronik.

\section{DAFTAR PUSTAKA}

1. Thomas B, Wulf S, Bikbov B, Perico $\mathrm{N}$, Cortinovis M, Courville K. Maintenance dialysis throughout the world in years 1990 and 2010. J Am Soc Nephrol. 2015; 26: 2621-2633.

2. U.S. Renal Data System (USRDS): USRDS 2013 Annual Data Report: Atlas of Chronic Kidney Disease and End-Stage Renal Disease in the United States, Bethesda, MD, National Institutes of Health, National Institute of Diabetes and Digestive and Kidney Diseases, 2013.

3. PERNEFRI. 10th Report of Indonesian Renal Registry. Perhimpunan Nefrolog Indonesia. 2017.

4. Cheung W, Paik K, Mak R. Inflammation and cachexia in chronic kidney disease. Pediatr Nephrol 2010; 25:711-24

5. Hosoya M, Kawamata Y, Fukusumi S, et al. Molecular and functional characteristics of APJ. Tissue distribution of mRNA and interaction with the endogenous ligand apelin. J Biol Chem. 2000.

6. Maguire J, Kleinz M, Pitkin S, et al. [Pyr1]Apelin-13 Identified as the Predominant Apelin Isoform in the Human Heart. Vasoactive Mechanisms 
and Inotropic Action in Disease. Hypertension. 2009

7. Foldes G, Horkay F, Szokodi I, et al. Circulating and cardiac levels of apelin, the novel ligand of the orphan receptor APJ, in patients with heart failure. Biochem Biophys Res Commun. 2003

8. Japp A, Cruden N, Barnes G, et al. Acute cardiovascular effects of apelin in man: potential role in patients with chronic heart failure. Circulation 2010.

9. Ishida J, Hashimoto T, Hashimoto Y. "Regulatory roles for APJ, a seventransmembrane receptor related to angiotensin-type 1 receptor in blood pressure in vivo". J. Biol. Chem. 279 (25): 26274-9. 2004.

10. Choi M, Ding Y, Kim S. TGF-beta signaling via TAK1 pathway: role in kidney fibrosis. Seminars in nephrology 32(3):244-252. 2012

11. Bircan B, Cakir M, Kirbag S, Gul H. Effect of apelin hormone on renal ischemia/reperfusion induced oxidative damage in rats. Ren Fail 38(7):11221128. 2016

12. Maezawa Y, Takemoto M, Yokote K. Cell biology of diabetic nephropathy: Roles of endothelial cells, tubulointerstitial cells and podocytes. Journal of diabetes investigation 6(1):315. 2015

13. Zhang B, Wang $\mathrm{W}$, Wang $\mathrm{H}$, Yin J, Zeng $\mathrm{X}$. Promoting effects of the adipokine, apelin, on diabetic nephropathy. PloS one 8(4):e60457. 2013.

14. Cox C, D'Agostino S, Miller M, Heimark R, Krieg P. Apelin, the ligand for the endothelial G-protein-coupled receptor, APJ, is a potent angiogenic factor required for normal vascular development of the frog embryo.
Developmental biology 296(1):177-189. 2006.

15. Day R, Cavaglieri R, Feliers D. Apelin retards the progression of diabetic nephropathy. American journal of physiology Renal physiology 304(6):F788-800. 2013

16. Guo C, Liu Y, Zhao W, Wei S, Zhang $\mathrm{X}$, Wang $\mathrm{W}$, et al. Apelin promotes diabetic nephropathy by inducing podocyte dysfunction via inhibiting proteasome activities. Journal of cellular and molecular medicine 19(9):2273-2285. 2015.

17. Giachelli C. Vascular calcification mechanisms. Journal of the American Society of Nephrology : JASN 15(12):2959-2964. 2004.

18. Yuan Z, Zhou Y, Liao X, Luo J, Shen $\mathrm{K}, \mathrm{Hu} \mathrm{Y}$, et al. Apelin attenuates the osteoblastic differentiation of aortic valve interstitial cells via the ERK and PI3-K/Akt pathways. Amino acids 47(12):2475-2482. 2015.

19. Han X, Wang L, Diao Z, Liu W. Apelin: A novel inhibitor of vascular calcification in chronic kidney disease. Atherosclerosis 244:1-8.2016. 